\title{
Mass balance, runoff and surges of Bering Glacier, Alaska
}

\author{
W. Tangborn \\ HyMet Inc., 13629 Burma Rd SW, Vashon Island, WA 98070, USA \\ Correspondence to: W. Tangborn (hymet01@gmail.com)
}

Received: 10 October 2012 - Published in The Cryosphere Discuss.: 7 December 2012

Revised: 3 May 2013 - Accepted: 3 May 2013 - Published: 27 May 2013

\begin{abstract}
The historical net, ablation and accumulation daily balances, as well as runoff of Bering Glacier, Alaska are determined for the 1951-2011 period with the PTAA (precipitation-temperature-area-altitude) model, using daily precipitation and temperature observations collected at the Cordova and Yakutat weather stations, together with the areaaltitude distribution of the glacier. The model mean annual balance for this $61 \mathrm{yr}$ period is $-0.6 \mathrm{~m}$ w.e., the accumulation balance is +1.4 and the ablation balance is $-2.0 \mathrm{~m}$ w.e. Average annual runoff is $2.5 \mathrm{~m}$ w.e. Periodic surges of this glacier transport large volumes of ice to lower elevations where the ablation rate is higher, producing more negative balances and increasing runoff. Runoff from Bering Glacier (derived from simulated ablation and precipitation as rain) is highly correlated with four of the glacier surges that have occurred since 1951. Ice volume loss for the 1972-2003 period measured with the PTAA model is $2.7 \mathrm{~km}^{3}$ w.e. $\mathrm{a}^{-1}$ and closely agrees with losses for the same period measured with the geodetic method. It is proposed that the timing and magnitude of daily snow accumulation and runoff, both of which are controlled by the glacier's area-altitude distribution and are calculated with the PTAA model, can be used to determine the probability that a glacier will surge.
\end{abstract}

\section{Introduction}

The Bering Glacier/Bagley Icefield in Alaska, the largest glacier/icefield complex in North America, is $180 \mathrm{~km}$ in length, ranges from sea level to $2445 \mathrm{~m}$ altitude and has a total area of about $4400 \mathrm{~km}^{2}$ (Fig. 1). Within the past 100$200 \mathrm{yr}$, Bering Glacier began to retreat from its maximum Neoglacial position; however, in the past $100 \mathrm{yr}$ this retreat has been interrupted by at least six surges of substantial amplitude and duration (Fleisher et al., 2010; Molnia and Post,
1995; Meier and Post, 1969; Burgess et al., 2012). Surges of this glacier influence its mass balance by transporting large masses of ice to lower altitudes, where higher temperatures increase ablation rates (Eisen et al., 2001). During the 1993 1995 surge, the average ablation balance determined by the PTAA model is $-3.3 \mathrm{~m}$ w.e., over a meter greater than the 1951-2011 average. Analysis of the link between Bering Glacier surges and englacial (liquid) water storage suggests surges might be predicted by monitoring stream discharge at the terminus (Fleisher et al., 2010; Muskett et al., 2003; Merrand and Hallet, 1996; Lingle and Fatland, 2003)

\section{The PTAA mass balance model}

\subsection{Model description}

The PTAA (precipitation-temperature-area-altitude) is a relatively simple model that requires only daily observations of precipitation and maximum and minimum temperatures collected at a standard, usually low-altitude weather station in the region of the glacier, plus the area-altitude distribution of the glacier's surface. It is similar to a degree-day model only in its weather data requirements; it does not require annual balance measurements for coefficient calibration as does a degree-day model.

Daily meteorological observations are converted to snow and ice ablation and snow accumulation at each area-altitude interval of the glacier by the following procedure:

- Linear regressions are developed between daily values of seven balance variables for each day of the summer season (approximately 1 June-30 September) (Table 1):

- The daily balance is found by summing the balance for each altitude interval times the area fraction of that interval Eq. (1): 


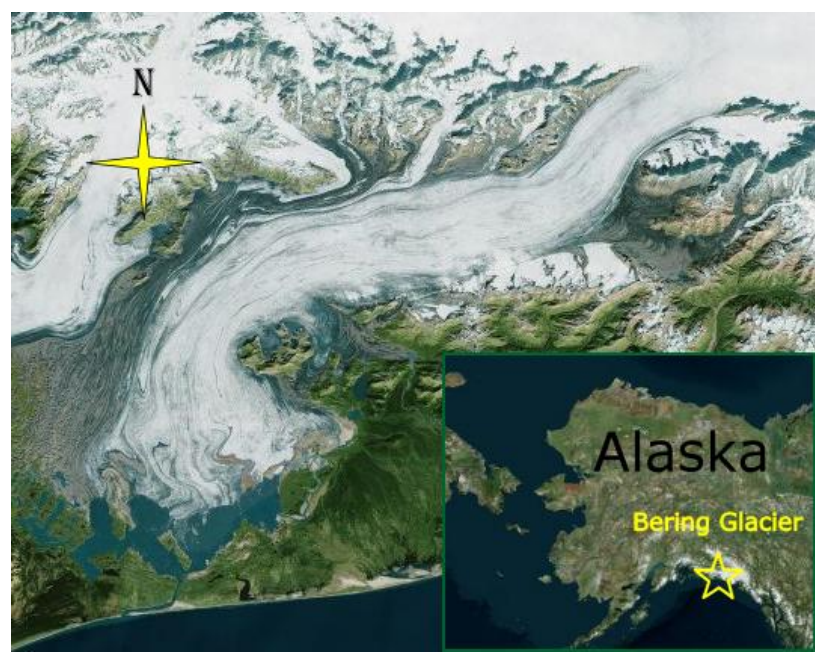

Fig. 1. Bing satellite image of the Bering Glacier terminus. A portion of the Bagley Ice Field is shown at the top of the image.

$j=49$ (glacier head)

$\mathrm{ba}(i)=\sum \mathrm{ba}(j)(\mathrm{aa}(j))$

$j=1$ (terminus),

where ba $(i)$ is daily balance in $\mathrm{m}$ w.e., $\mathrm{ba}(j)$ is balance for altitude interval $j$ in $\mathrm{m}$ w.e., aa $(j)$ is altitude interval $j$, in fraction of the total glacier area.

- The daily balance is summed for a year to produce the annual balance Eq. (2):

Sep 30

$\mathrm{Ba}(n)=\sum \mathrm{ba}(i)$

Oct 1 ,

where $\mathrm{Ba}(n)$ is annual balance for year $n$ in $\mathrm{m}$ w.e.

Fifteen coefficients are used in algorithms (equations) to calculate the seven variables (Table 2). Ten linear regressions are run using combinations of the seven balance variables. A regression error is determined for each day of the ablation season (about 1 June-30 September) and averaged for each year. The average error produced by these regressions is minimized by simultaneously adjusting the coefficients with a simplex, which is a numeric method of solving problems in linear programming (Nelder and Mead, 1965). Minimizing the calibration error also minimizes the error produced by calculating the annual balance from weather observations. It is the combination of these error minimization procedures that is the basis of the PTAA model.

For Bering Glacier, the daily balance is determined using the area-altitude distribution shown in Fig. 2. There are other
Table 1. PTAA model variables.

\begin{tabular}{lll}
\hline 1. & $\mathrm{B}_{\mathrm{c}}$ & (Snow accumulation) \\
2. & $\mathrm{B}_{\mathrm{S}}$ & (Ablation) \\
3. & $\mathrm{B}_{\mathrm{a}}$ & (Balance) \\
4. & $\mathrm{SLe}$ & (Snowline attitude) \\
5. & $\mathrm{Ex}$ & (Balance flux) \\
6. & $\mathrm{AAR}$ & (Accumulation area ratio) \\
7. & ZBA & (Zero balance altitude) \\
\hline
\end{tabular}

Table 2. Mass balance coefficients.

$C_{1}, C_{2}, C_{3}$ converts gauge to glacier precipitation
$C_{4}$ ablation mixing factor
$C_{5}, C_{6}, C_{7}, C_{8}$ determines temperature lapse rate
$C_{9}$ multiplier for ablation from temperature when $p=0.0$
$C_{10}$ multiplier for ablation from temperature when $p>0.0$
$C_{11}$ multiplier for ablation due to radiation below snowline
$C_{12}$ multiplier for solar radiation
$C_{13}$ multiplier to raise seasonal snowline
$C_{14}$ multiplier to raise transient snowline
$C_{15}$ multiplier for internal accumulation

AA distributions for Bering Glacier available but this is the only one that is derived from USGS topographic maps and is credible. Also used are the daily temperature and precipitation observations at Yakutat and Cordova, Alaska, located approximately $125 \mathrm{~km} \mathrm{NW}$ and $200 \mathrm{~km} \mathrm{SE}$ of the glacier terminus, and at elevations of 8 and $12 \mathrm{~m}$, respectively.

The PTAA model relies on the climate history that is embedded in a glacier's area-altitude (AA) distribution. The AA distribution is developed by glacier flow and erosion of the underlying bedrock over geologic time, both of which are dependent on long-term-mass balances and on the climate.

The glacier's surface is therefore a reflection of its bed and holds the key that relates mass balance to the climate. In the calibration process minute alterations are automatically made by the simplex in the input variables of simulated temperature and precipitation that are determined by the area and elevation of each AA interval on the glacier's surface.

\subsection{Model calibration}

The PTAA model is calibrated by calculating the daily balance for each altitude interval and for each day of the 19512011 period, using 15 coefficients and a simplex optimizing procedure. The simplex automatically and simultaneously calculates optimum values for all 15 coefficients. The annual balance is found by integrating daily balances over one year. The coefficients convert observed precipitation and temperature at the two low-altitude weather stations to daily snow accumulation and snow and ice ablation. Physical explanations for each coefficient are provided in Tangborn (1999).

The area-altitude distribution in Fig. 2 was developed from 1972 USGS topographic maps, Arendt et al. (2002) 


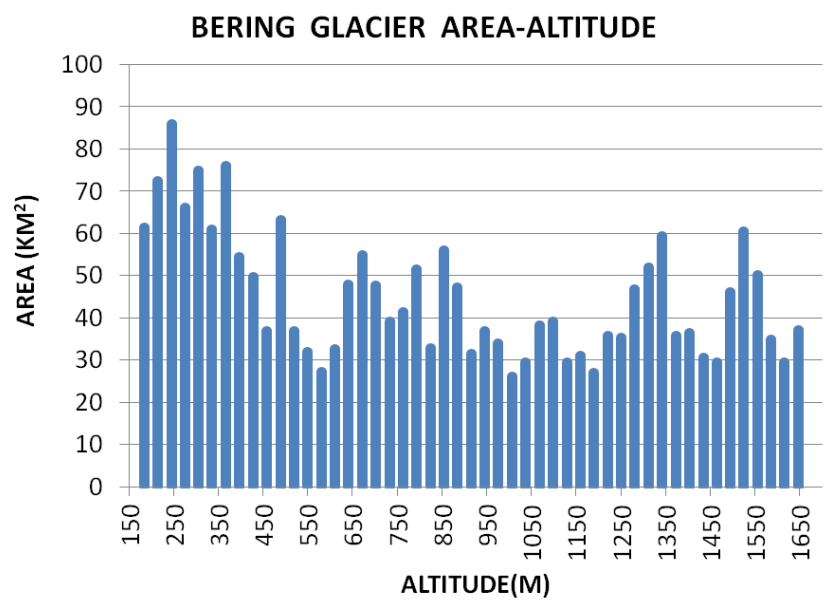

Fig. 2. Area-altitude distribution of Bering Glacier. There are 49 altitude intervals spaced at $30.6 \mathrm{~m}$ (100 feet), ranging from 150 to $1650 \mathrm{~m}$ in elevation. The total area of this segment is $2193 \mathrm{~km}^{2}$ and includes the most active (surging) area of the glacier. These area distributions do not cover the full range of the glacier area that includes the Bagley Ice Field. Latitude $60.302^{\circ} \mathrm{N}$ Longitude $143.20^{\circ} \mathrm{W}$.

(designated (GS) for Geological Survey). There are 49 intervals spaced at $30.48 \mathrm{~m}$ (100 feet) with a total area of $2193 \mathrm{~km}^{2}$. The total area defined by Beedle et al. (2008) of the Bering Glacier System (BGS) is $4373 \mathrm{~km}^{2}$ or exactly twice the area (within a few $\mathrm{km}^{2}$ ) of the area in GS, (Beedle et al., 2008). The Bering Glacier System outline includes all ice within the US Board on Geographic Names definition of BGS and excludes nunataks and areas of debris cover).

Each interval of the area-altitude distribution in GS is divided by the total area to produce a dimensionless fraction that is used for the model calibration Eq. (3).

The total area of GS is

$i=49(1650)$

$A_{t}=\sum \mathrm{aa}_{i}=$ total area $=2193 \mathrm{~km}^{2}$

$i=1$ (terminus),

$\mathrm{aa}_{f}$ is $\mathrm{aa}_{i} / A_{t}$ where aa $\mathrm{a}_{f}$ is fraction of total area for interval $i$, $\mathrm{aa}_{i}$ is area of interval $i$ in $\mathrm{km}^{2}, A_{t}$ is area of GS in $\mathrm{km}^{2}$.

The area for each interval in BGS is found by scaling the total area $\left(4373 \mathrm{~km}^{2}\right)$ with GS (which assumes the area distribution pattern in BGS is approximately equal to the distribution in GS) Eq. (4).

$\mathrm{AA}_{i}=\operatorname{aa}_{f}(\mathrm{BGS})$,

where $\mathrm{AA}_{i} i$ sarea of interval $i$ in $\mathrm{km}^{2}$;

therefore, for BGS:

$i=49(1650)$

$A_{T}=\sum \mathrm{AA}_{i}=$ total area $=4373 \mathrm{~km}^{2}$

$i=1$ (terminus).
The area intervals, $\mathrm{AA}_{i}, i=1,49$ are then used for determining optimum coefficients to calculate the annual balance.

The initial $15(n)$ coefficient values are random estimates, based on a physically real range of potential values for each parameter. For example, the coefficient that converts gauge precipitation to glacier precipitation is assigned $16(n+1)$ different values that vary from 0.100 to 0.300 . The final value after 350 iterations and the calibration completed is 0.2007 (a noteworthy finding is that the coefficients must be calculated to 16 decimal places or the simplex will not close). Similar estimates are made for initial values of the other 14 coefficients. The annual balances shown for each iteration in Fig. 3 are based on the initial coefficient estimates of the 16 coefficients. The first 16 balances vary from approximately -1.5 to $+2.0 \mathrm{~m}$ w.e. corresponding to the initial, pre-set coefficient values. As the calibration proceeds, coefficient values are determined automatically by the simplex.

One iteration of the simplex determines for each elevation level the daily and annual balances for the period of record, and calculates the average error that occurs when multiple balance parameters are regressed against each other. The average root-mean-square-error resulting from these regressions is minimized by the simplex to obtain optimum coefficient values. The size of the error automatically determines the minute adjustment that is made to each coefficient for the next iteration. After approximately 350 iterations, the calibration error usually reaches a minimum (in this case about $45 \%$ ), and the mean annual balance is an optimum value (in this case about $-0.6 \mathrm{~m}$ w.e.). The PTAA model is based on minimizing the regression errors averaged for ten pairs of two related balance variables using the same meteorological observations for all calculations. These regression errors predict the error that is produced when a glacier's mass balance is calculated from weather observations.

The scatter plot in Fig. 4 shows the mean annual balance versus the corresponding error for each iteration. When the error is a minimum at $45 \%$, the mean annual balance is $-0.60 \mathrm{~m}$ w.e. For most glaciers that have been studied the balance-error distribution shows a more distinct mean balance value. The immense size of the Bering Glacier may tend to reduce the balance-error distinction and make the determined mean annual balance less definite. The curvature of balance versus error envelope in Fig. 4 is low, suggesting a large balance error. Other glaciers in this study have a more well-defined balance-error distribution than Bering Glacier (www.ptaagmb.com).

\section{Mass balance results}

The immense area of Bering Glacier precludes annual balance measurements by traditional means, i.e. by measuring snow density in snow pits and setting ablation stakes. The alternatives are geodetic volume measurements or a physical model, such as the PTAA model. A degree-day type model is 


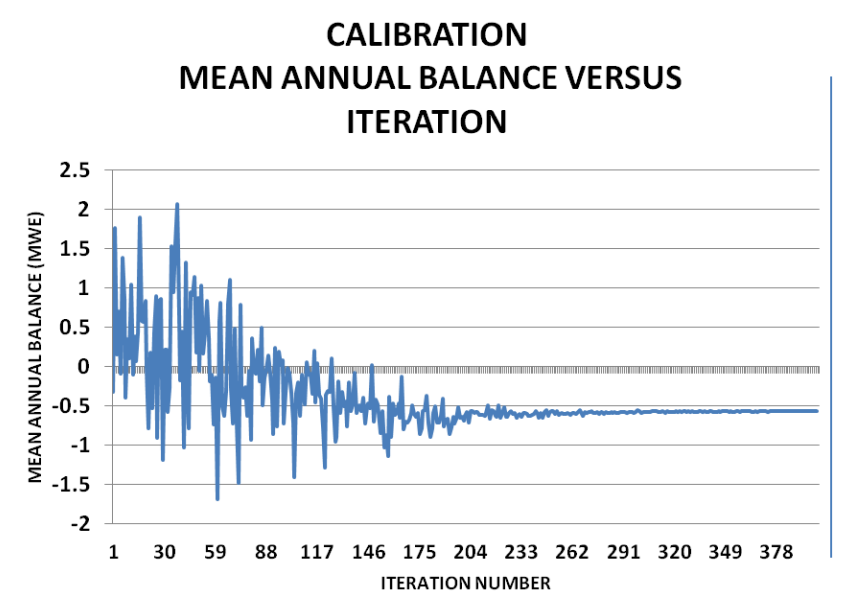

Fig. 3. Mean annual balance versus iteration number of the optimizing simplex. Balances 1-15 are derived from preset coefficients. Balances 16-400 are calculated automatically from coefficients determined by the simplex optimizing process. When the calibration error reached a minimum, the average annual balance was $-0.6 \mathrm{~m}$ w.e., or $-26.4 \mathrm{~km}^{3}$ for the $1951-2011$ period.

\section{MEAN ANNUAL BALANCE VERSUS CALIBRATIONERROR}

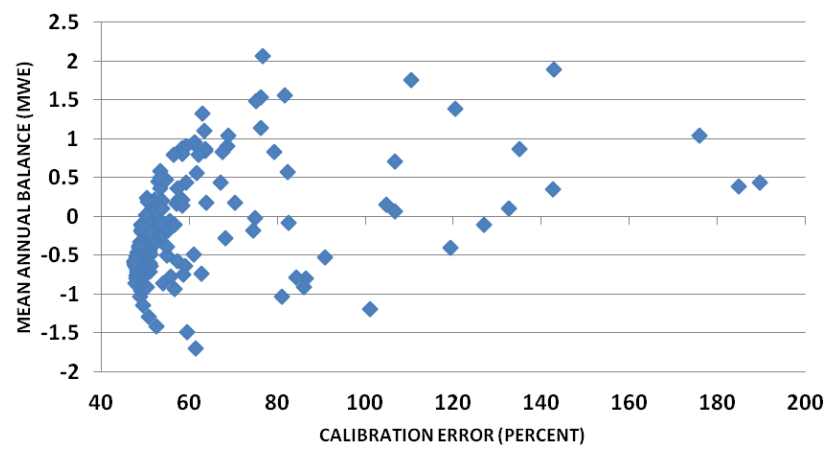

Fig. 4. Mean annual balance versus calibration error. When the calibration error reached the minimum of about $45 \%$, the average annual balance is $-0.6 \mathrm{~m}$ w.e. Each point represents the mean annual balance based on one year of daily balance determinations.

not appropriate for this glacier because manually measured annual balances are not available.

The annual balance for Bering Glacier for each year of the 1951-2011 period is calculated with the PTAA model using two low-elevation weather stations (Fig. 5). The average net annual balance for $61 \mathrm{yr}$ is $-0.6 \mathrm{~m}$ w.e., the mean accumulation balance is $+1.4 \mathrm{~m}$ w.e. and the ablation balance is $-2.0 \mathrm{~m}$ w.e. (Fig. 6). Total thinning averaged over the glacier surface for $61 \mathrm{yr}$ is $39 \mathrm{~m}$ of ice or $0.6 \mathrm{~m}$ of ice per year (Fig. 7). The net balance is equal to the accumulation minus the ablation balance, or $\left(b_{\mathrm{n}}=b_{\mathrm{w}}-b_{\mathrm{s}}\right)$, where $b_{n}$ is $\sum b_{\mathrm{aa}}$, and $b_{\mathrm{aa}}$ is balance at area-altitude fraction aa. An advantage of the PTAA model is that it produces daily bal-

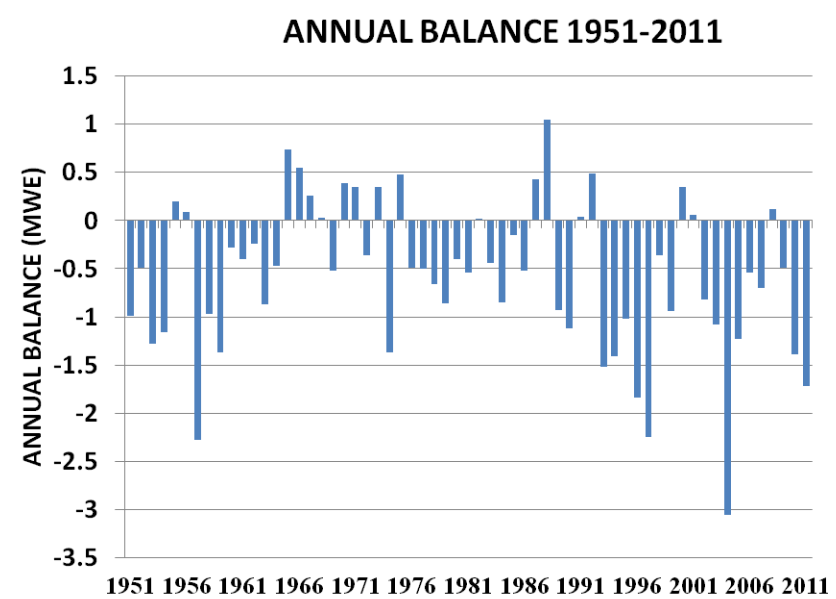

Fig. 5. Annual balance of the Bering Glacier for the 1951-2011 period. The average annual balance is $-0.6 \mathrm{~m}$ w.e. The minimum balance for the period (-3.1 $\mathrm{m}$ w.e.) occurred in 2004 .

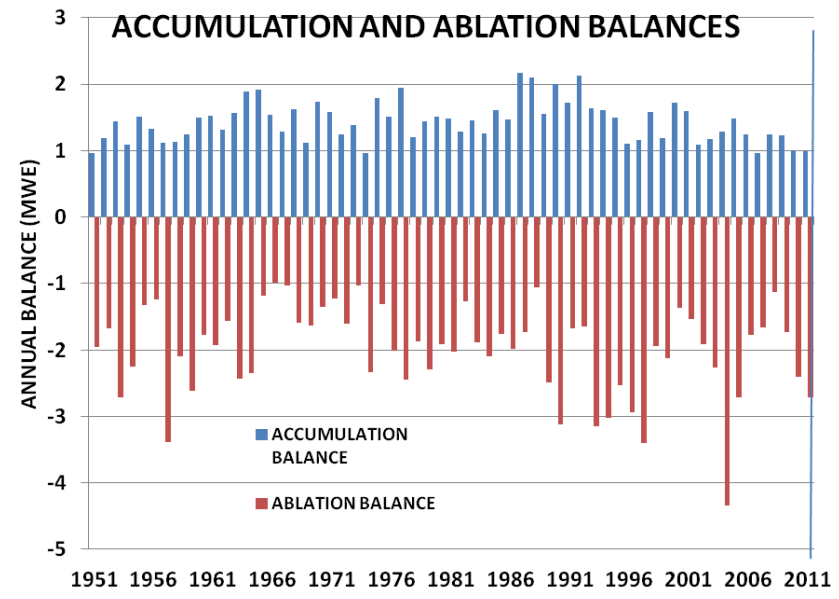

Fig. 6. Accumulation and ablation balances for the 1951-2011 period. The average annual accumulation balance for this period is +1.4 and the average ablation balance is -2.0 ( $\mathrm{m}$ w.e.). Maximum ablation (-4.3 m w.e.) occurred in 2004.

ances for each area-altitude interval and for the total glacier, therefore balance results can be clearly displayed in a format similar to hypothetical daily balances suggested in earlier publications (Meier, 1962; Anonymous, 1969 and Mayo et al., 1972). The terms accumulation and ablation balance were introduced in Tangborn and Rana (2000) to reduce the confusion caused by cumulative snowfall in the Himalayas during the monsoon season of June-September being designated "winter balance". Also, ablation at lower elevations in the Himalayas often occurs during the winter months, therefore "summer balance" is incorrect.

The PTAA model was developed as an alternative to other methods of measuring glacier mass balances. One of its advantages is that the only data requirements are daily observations of precipitation, and maximum and minimum 
temperatures at a nearby weather station (or an average of two stations) and the area-altitude distribution of the glacier's surface. For some glaciers, the weather stations can be as far as $300 \mathrm{~km}$ from the glacier but usually the distance is closer to $100 \mathrm{~km}$ or less. The area-altitude distribution (hypsometry) is developed from DEM models or topographic maps. A finely divided area interval produces the most accurate results, e.g. a $10 \mathrm{~m}$ interval between areas is preferable to $50 \mathrm{~m}$.

\subsection{Validation}

The elevation change and volume loss of Bering Glacier have been estimated by different authors using remote-sensing techniques (Arendt et al., 2002; Beedle et al., 2008; Muskett et al., 2009; Berthier et al., 2010; Berthier, 2010). For the period 1972-2003, using the 1972 USGS map as a reference and a glacier area of $4400 \mathrm{~km}^{2}$, the geodetic method (ASTER DEM), volume loss for the entire Bering Glacier system equaled $2.6 \pm 0.5 \mathrm{~km}^{3}$ w.e. $\mathrm{a}^{-1}$ (Berthier, 2010). For the same $31 \mathrm{yr}$ period, the PTAA model cumulative balance change (Fig. 4), using an area of $4373 \mathrm{~km}^{2}$, is $-16.8 \mathrm{~m}$ w.e. or $-0.54 \mathrm{~m}$ w.e. $\mathrm{a}^{-1}$ or $-2.4 \mathrm{~km}^{3}$ w.e. $\mathrm{a}^{-1}$, slightly less than the rate of volume loss determined by the geodetic method (Fig. 7).

The PTAA model was first applied to determine annual balances of Columbia Glacier in Alaska (Tangborn, 1997), and to South Cascade Glacier where it was compared with manually measured balances for the 1959-1996 period (Tangborn, 1999). It was used to calculate the mass balance and runoff of the debris-covered Langtang Glacier, located in the Himalayan Range in Nepal (Tangborn and Rana, 2000). The PTAA model has also been applied to two other glaciers in Alaska (Gulkana and Wolverine to determine annual balances that are then compared with manual balances measured by the USGS (Bhatt et al., 2007; Korn, 2010; Zhang, et al., 2007a, b)). Application to the north-facing and south-facing glaciers in the Wrangell Range in Alaska, provides an insight into the cause of ablation variations and suggests a causal link between ablation of Wrangell glaciers and global temperature anomalies (Tangborn, 2012).

\subsection{Balance versus elevation}

As are most temperate glaciers, Bering Glacier mass balance is dependent on elevation, varying from less than an average of $-8 \mathrm{~m}$ w.e. at the terminus to an accumulation balance of over $2 \mathrm{mw}$.e. at $1600 \mathrm{~m}$. Thus, there is a minimum of $2 \mathrm{~m}$ of ice $\left(4.4 \mathrm{~km}^{3}\right)$ added to the surface of the upper glacier (above the ELA) each year that provides the ice mass to feed a surge if we assume $2 \mathrm{~m}$ as a minimum of net accumulation in the entire glacier basin above the mean ELA at $1550 \mathrm{~m}$. This gives a volume accumulation of $4.4 \mathrm{~km}^{3}\left(2 \mathrm{~m}\right.$ w.e. $\left.\times 2200 \mathrm{~km}^{2}\right)$, which is the entire glacier area above the mean ELA. Therefore, the balance-altitude

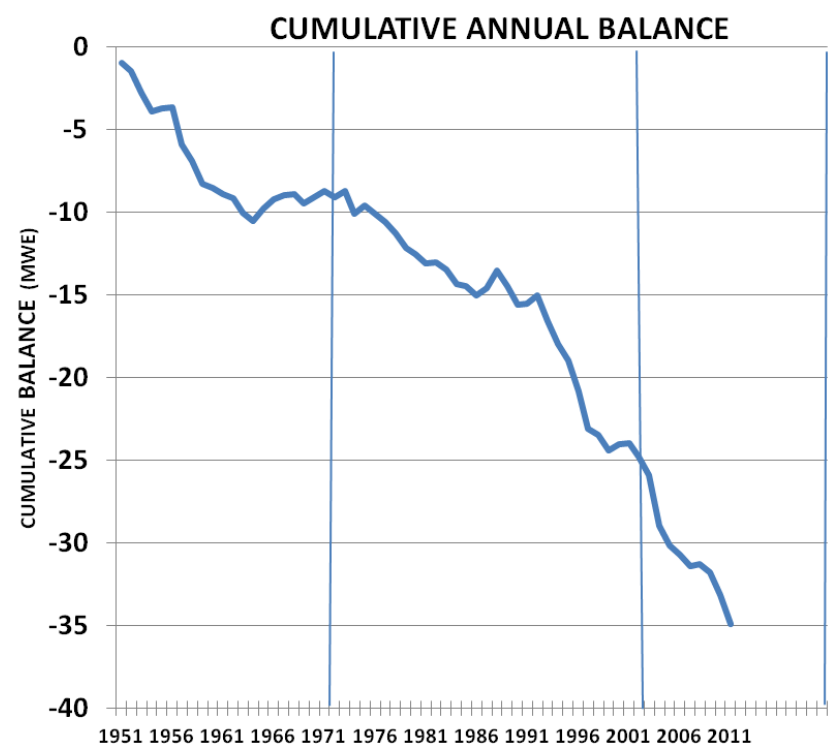

Fig. 7. Cumulative balance of Bering Glacier. Total thinning during this $61 \mathrm{yr}$ period is $39 \mathrm{~m}$ or $0.6 \mathrm{~m}$ of ice per year. The vertical lines at 1972 and 2003 delineate the period for which the volume loss determined by the PTAA and geodetic methods is compared. Volume loss for this $31 \mathrm{yr}$ period determined geodetically is $2.6 \pm 0.5 \mathrm{~km}^{3}$ w.e. $\mathrm{a}^{-1}$. The PTAA model loss for the same period is -16.8 m w.e. $\left(-0.54\right.$ m w.e. $\mathrm{a}^{-1}$ or $-2.4 \mathrm{~km}^{3}$ w.e. $\left.\mathrm{a}^{-1}\right)$.

gradient, $b(z)$, is considered to be a factor for determining the probability that a glacier will surge.

The net, accumulation and ablation balances as a function of elevation are shown in Fig. 8a, averaged for the 19512011 period, and in Fig. 8b for the 2004 balance year. The widespread forest fires in Alaska in 2004 emitted ash and particulates that decreased the albedo of the glacier surface and strongly affected mass balances (Figs. 5 and 6). The contrast between $b(z)$ curves in Fig. 8a and $\mathrm{b}$ demonstrates how ablation and the ELA of Bering Glacier were affected by these wildfires and by higher than normal temperatures during the 2004 summer. Ablation at the terminus increased from an average of $5 \mathrm{~m}$ w.e. to $14 \mathrm{~m}$ w.e. and the ELA moved up $300 \mathrm{~m}$, from $1550 \mathrm{~m}$ average elevation to $1850 \mathrm{~m}$ in 2004 . The annual balance in 2004 ( $-3.1 \mathrm{~m}$ w.e.) is the most negative for the 1951-2011 period of record.

\subsection{Real-time glacier balances}

The daily mass balances (net, accumulation and ablation) are calculated continuously throughout the period of record, and can be determined for any day if the meteorological observations are available in real-time. One goal of this project is to continuously monitor all the glaciers in the study (eventually 200) and display the current mass balance of each one, in real time, if up-to-date weather observations are available, or near real time if weather observations are delayed. The daily balances for the 2011 balance year shown in Fig. 9 demonstrate 
(a)

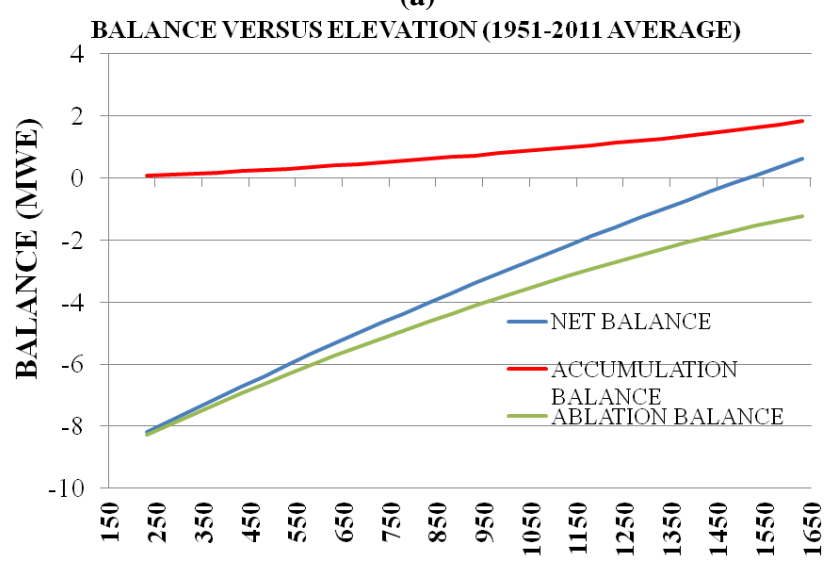

ELEVATION (M)

(b)

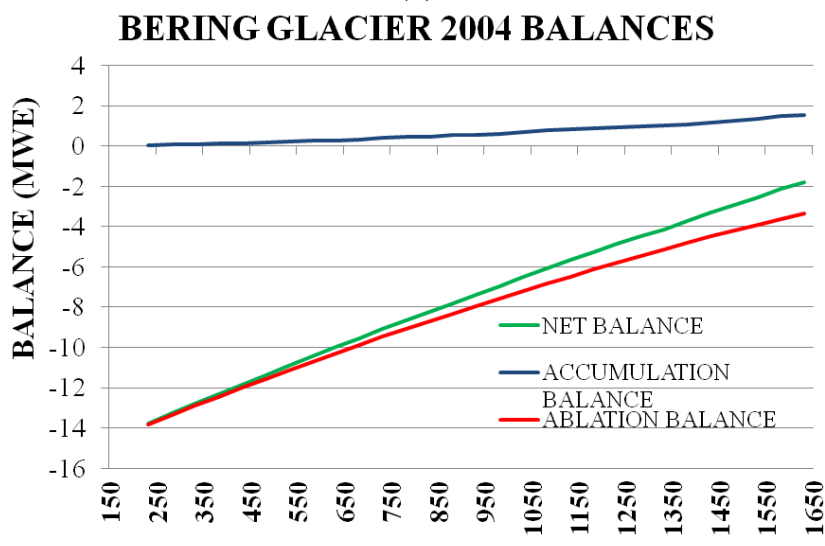

ELEVATION (M)

Fig. 8. (a) Net, accumulation and ablation balances of Bering Glacier as a function of elevation, averaged for the 1951-2011 period. The ELA $(1550 \mathrm{~m})$ is defined as the point at which the net balance crosses the zero balance line. (b) Net, accumulation and ablation balances of Bering Glacier as a function of elevation, averaged for 2004. The ELA is $1850 \mathrm{~m}, 300 \mathrm{~m}$ above average. The balance at the terminus ( $-14 \mathrm{~m}$ w.e.) is nearly 3 times as negative as on a normal year.

how real-time mass balances for Bering Glacier will be displayed in future years.

For example, on 30 September, 2011, the Net Balance is $-1.7 \mathrm{~m}$ w.e., the Accumulation Balance, $1.0 \mathrm{~m}$ w.e., and the Ablation Balance, $-2.7 \mathrm{~m}$ w.e. Simultaneous analysis of the daily balances of a large number of glaciers will be applied to provide an improved understanding of glacier/climate relationships.

\subsection{Bering surges, snow accumulation and runoff}

Englacial (liquid) water storage in a temperate glacier is calculated by input and output observations of precipitation and runoff (Tangborn et al., 1972) and is considered a critical fac-

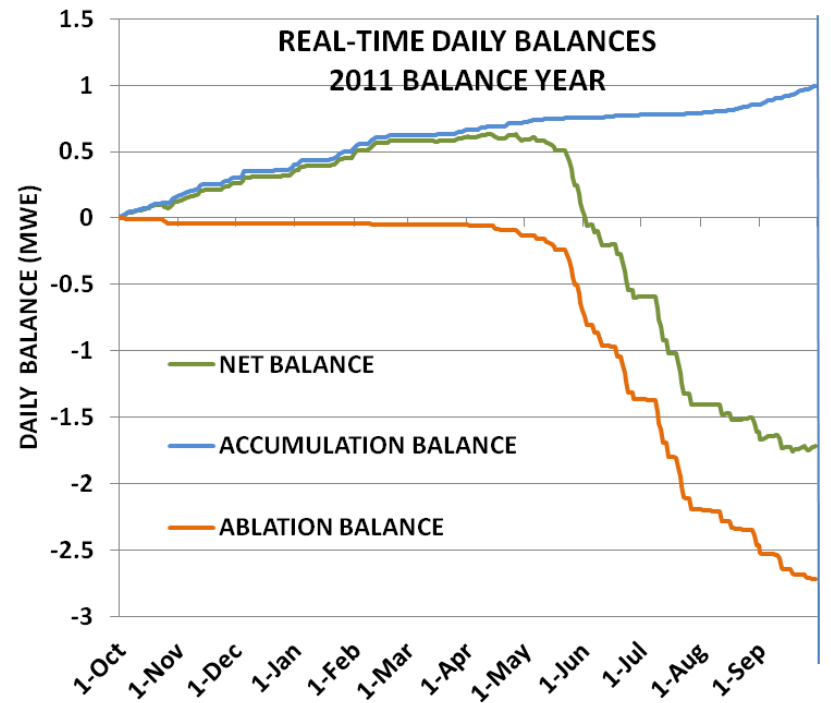

Fig. 9. Daily balances of Bering Glacier during the 2011 balance year. The final net balance for 2011 on 30 September equals $-1.7 \mathrm{~m}$ w.e., the accumulation balance is 1.0 and the ablation balance is $-2.7 \mathrm{~m}$ w.e. Snow accumulation on Bering Glacier begins on approximately 1 August each year, thus "winter" balance is a misnomer for this glacier.

tor in glacier surges (Kamb, 1987; Merrand and Hallet, 1996; Fatland and Lingle, 1998). During the 1993-1995 surge of Bering Glacier, downward movement of englacially stored water produced a failure of subglacial till, causing rapid basal sliding (Lingle and Fatland, 2003). One year after the surge began in 1993, an outburst of pressurized subglacial water temporarily halted sliding and slowed the ice front advance (Fleisher et al., 2010). Measurements of water discharge at the terminus during surges indicate that high rates of discharge are associated with major surge events (Merrand and Hallet, 1996).

Runoff during the summer months for most Alaska glaciers that extend to lower elevations often exceeds $2 \mathrm{~m}$ due to high ablation rates. During quiescent phases, the basal hydraulic system of a glacier has the ability to develop a channelized drainage system that allows rapid flows and prevents hydraulic pressurization of the bed (Rothlisberger, 1972).

The reason why some glaciers surge and others do not is not fully understood, but is likely related to the combination of its area-altitude distribution and the distribution and magnitude of its daily mass balance and daily runoff (runoff is defined as the sum of ablation, precipitation as rain and release of water from englacial storage). Therefore, predicting whether a specific glacier will surge is feasible if its surface configuration (area-altitude distribution), and historical records of daily balance and runoff are available. We suggest that periodic surges of some glaciers are caused by a build-up of mass on the mid to upper glacier from the accumulation of snow, coupled with an influx of water to the glacier bed. 
When critical mass has accumulated, a surge is triggered by an influx of water (runoff plus release of englacial storage) to the glacier bed and the storage reservoir of ice on the upper glacier is depleted. These two phenomena (snow accumulation and runoff) tend to be mutually exclusive; high rates of snowfall and runoff from ablation and precipitation as rain usually do not occur simultaneously. Therefore, the timing of snow accumulation and runoff is critical for a surge to occur. The area-altitude distribution of the glacier surface controls both snow accumulation and runoff, therefore is also a determining factor that causes a glacier to surge ${ }^{12}$. Mass balance has been shown to be an influential factor for surges of glaciers in Svalbard (Dowdeswel et al., 1995).

For Bering Glacier, the mass accumulation of snow at higher elevations is nearly continuous at higher elevations. Snow accumulation, estimated at each elevation level of the glacier, is derived from temperature and precipitation observations at the two weather stations. If the calculated temperature (based on the simulated lapse-rate) at the interval elevation is equal or less than $0^{\circ} \mathrm{C}$, precipitation occurs as snow; if it is greater than zero, precipitation occurs as rain. Total annual snow accumulation on the glacier is determined by summing each elevation estimate of snow beginning on 1 October each year. Therefore, the runoff and snow accumulation curves shown in Fig. 10 are related by both precipitation and temperature variations. Runoff during the 1994 surge was measured together with sediment discharge into Vitus Lake (Merrand and Hallet, 1996). A peak discharge of $1800 \mathrm{~m}^{3} \mathrm{~s}^{-1}$ occurred in August, five times the estimated average discharge. A large proportion of the discharge peak is water released from englacial storage although the amount and timing is unknown.

Surges of Bering Glacier can produce an ice displacement as much as $13 \mathrm{~km}$ from mid-glacier to the terminus (Post, 1972). Transporting large volumes of ice to a lower and warmer elevation over a short time period (several months) increases the ablation rate and alters the mass balance and runoff of a glacier. Observed surges occurred in 1958-1960, 1966-1967, 1981, 1993-1995 and 2008-2011 (Molnia and Post, 2010). An increase in runoff caused by increased ablation during these periods would therefore be expected if there is a large transport of ice to lower elevations during a surge.

A plot of Bering Glacier cumulative $5 \mathrm{yr}$ running mean of both runoff and snow accumulation, shown in Fig. 10, suggests a causal relationship between surges and runoff. A notable exception is the 1966-1967 surge that did not increase

\footnotetext{
${ }^{1}$ A preliminary report. Tangborn, W. V.: Connecting winter balance and runoff to surges of the Bering Glacier, Alaska, Alaska, A preliminary report, HyMet Inc., Seattle, W.A., http://www.hymet. com, 2002.

${ }^{2}$ A preliminary report. Tangborn, W. V.: Mass balance, runoff and internal water storage of the Bering Glacier, Alaska (19501996), A preliminary report, Hymet Inc., Seattle, W. A., http://www. hymet.com, 1999.
}

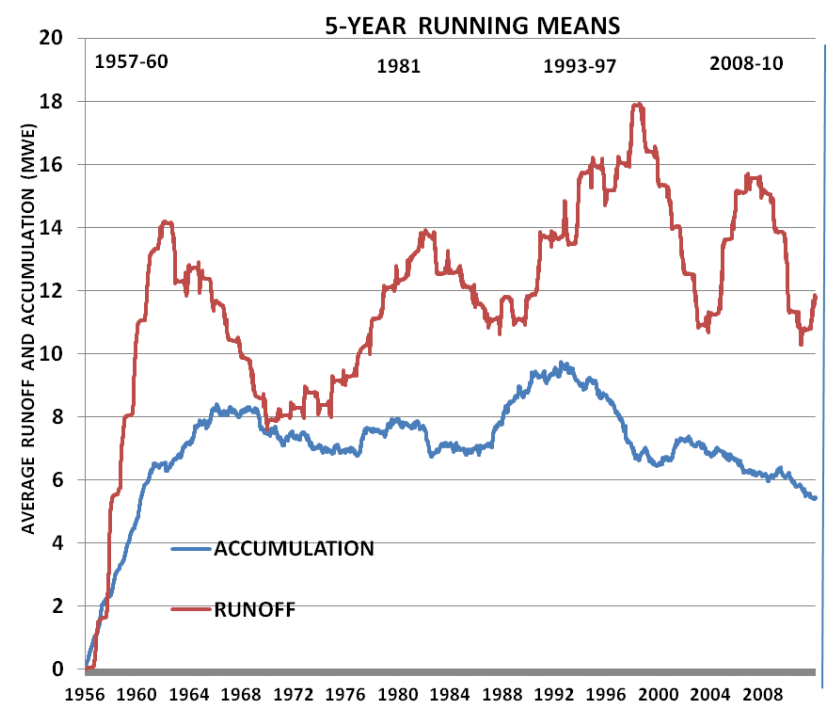

Fig. 10. Five-year running mean of daily runoff (ablation plus precipitation as rain) and snow accumulation on Bering Glacier, and timing of four of the observed surges since 1951. The 1966-1967 surge appears not to have affected runoff.

runoff, although it was not observed and only indirect information regarding this surge is available (Fleisher et al., 2010; P. J. Fleisher, personal communication, 2013). The relationship between surges and snow accumulation is less clear. However, there is a pronounced increase in snow accumulation in the mid-1990s that is a precursor and appears to be one of the main causes of the 1993-1997 surge. Each point on these curves represents cumulative runoff or snow accumulation averaged for the previous $5 \mathrm{yr}$. For example, on 1 October 1981, a total of $14 \mathrm{~m}$ w.e. runoff had occurred over the previous $5 \mathrm{yr}$, or $2.8 \mathrm{~m}$ w.e. per year. Also shown is the timing of four of the five observed surges since 1951. Peak runoff occurs near the midpoint of each surge.

Cumulating daily snowfall averaged over the total glacier area in $5 \mathrm{yr}$ running averages demonstrates the variations in glacier mass that have occurred throughout the period of record, 1956-2011. The pattern of the running accumulation balance differs from the runoff pattern. Bering surges are a reflection of these differences, confirming that surges are initiated by a build-up of mass, then proceed by the introduction of bed-lubricating water.

A surge usually ends when there is a rapid release of stored water (jökulhlaup) that depletes the water supply for bed lubrication. Basal glide from water lubrication for surging glaciers in Iceland is suggested by a general lack of push-moraine formation in front of an advancing terminus (Bjornsson, 1998). It was first thought that the July 1994 observed Bering Glacier jökulhlaup was a surge-ending event because ice velocities decreased following the onset of the jökulhlaup. However, rapid ice movement restarted and the surge continued throughout 1995 (Fleisher et al., 2010). 
Runoff during the 1993-1995 surge was greater than for the other three as indicated in Fig. 10, and is likely due to greater release of englacial storage during this surge.

\section{Discussion}

\subsection{Terminology}

Mass balance terminology used in this report deviates from that proposed by the IACS Working Group of Mass Balance Terminology and Methods (Cogley et al., 2011), and more closely follows the mass balance definitions proposed in Meier (1962), Anonymous (1969), and Mayo et al. (1972).

Depicting elevation as dependent on mass balance as suggested on Fig. 8 in the IACS report creates a problem for modeling mass balance based on meteorological observations. There are eighteen algorithms used in the PTAA model to generate daily balances (Tangborn, 1999). A PDF of this paper is on www.ptaagmb.com (under How It Works). Fourteen of them incorporate elevation in the equation that determines daily balance from weather observations (Eq. 1, 2, $4-9,12-18)$. It would not be possible to make these calculations if elevation is treated as the dependent variable. After the daily and annual balances have been determined the results can of course then be plotted with elevation as the dependent variable as is suggested in Cogley et al. (2011).

The terms accumulation balance and ablation balance are preferred over winter balance and summer balance that are used in the IACS report. For most Alaskan glaciers, snow accumulation at higher elevations occurs throughout the year and can be especially heavy in August and September (Fig. 9). For many Himalayan Range glaciers, snow accumulation is greatest during the summer months of the monsoon season, from June through September. At lower elevations in the Himalayas, ablation often occurs during the winter months (Tangborn and Rana, 2000).

\subsection{Verification of the PTAA model}

The accuracy of annual balance results produced by the PTAA model is verified by comparing the annual with measured balances recorded for four glaciers, three of them located near Bering Glacier. Additional comparisons will be shown when measured balance records become available for other glaciers. Comparisons made for PTAA and measured net, accumulation and ablation balances for $50-60 \mathrm{yr}$ periods for the Gulkana, Wolverine, Lemon Creek and Vernagt glaciers can be viewed on www.ptaagmb.com.

\subsection{Runoff and observed surges}

Average runoff from Bering Glacier is estimated with the PTAA model by the sum of simulated ablation and precipitation as rain (the release of water from englacial storage is disregarded for a long-term average): $\mathrm{r}=\mathrm{a}+\mathrm{p}_{\mathrm{r}}$, where $\mathrm{r}$ is runoff, $\mathrm{a}$ is ablation, $\mathrm{p}_{\mathrm{r}}$ is precipitation as rain, all in units of length averaged over the glacier area. One millimeter of runoff per year averaged over $4440 \mathrm{~km}^{2}$ equals an average discharge rate of $0.15 \mathrm{~m}^{3} \mathrm{~s}^{-1}$, thus $2.5 \mathrm{~m}$ of runoff per year (approximately the long-term average) equals $375 \mathrm{~m}^{3} \mathrm{~s}^{-1}$. Based on a $60 \mathrm{yr}$ meteorological record, approximately $20 \%\left(75 \mathrm{~m}^{3} \mathrm{~s}^{-1}\right)$ of mean simulated discharge is due to precipitation as rain and $80 \%$ due to ablation.

\subsection{Validation}

Ice volume loss averaged for the 1972-2003 period, determined by the PTAA model and the geodetic method, averages $2.4 \mathrm{~km}^{3}$ and $2.6 \mathrm{~km}^{3}$, respectively, each year. Both methods contribute to the difference, $0.2 \mathrm{~km}^{3}$; consequently the PTAA model error is less than $0.2 \mathrm{~km}^{3}$ (1.4 m w.e.). The average PTAA model error for this $31 \mathrm{yr}$ period is therefore less than $1.4 \mathrm{~m}$ w.e. For comparison, the root mean square error for predicting annual balances of the Gulkana Glacier, based on balances measured by the USGS, is about $1.5 \mathrm{~m}$ w.e. (Fig. 9b on the Gulkana report at www.ptaagmb.com).

\section{Conclusions}

The daily and annual mass balance of Bering glacier for the 1951-2011 period is calculated with the PTAA model using low-altitude weather observations and the glacier's areaaltitude distribution. Validation of the model balance is made by comparison with the geodetic balance determined for the 1972-2003 period. Based on these results, we conclude that the timing and magnitude of daily snow accumulation and runoff, both of which are controlled by the glacier's area-altitude distribution and are calculated with the PTAA model, could be used to determine the probability that Bering Glacier will surge.

Acknowledgements. Austin Post's in-depth knowledge of Bering Glacier and his guidance for the past half-century is gratefully acknowledged. Reviews by Matthew Beedle, Etienne Berthier, Jay Fleisher, Craig Lingle, Robert McNabb, Mauri Pelto and Al Rasmussen all contributed to improving this paper. Funding for this project was provided by HyMet Inc.

Edited by: J. O. Hagen

\section{References}

Anonymous: Mass Balance Terms, J. Glaciol., 8, 3-7, 1969.

Arendt, A. A., Echelmeyer, K. A., Harrison, W. D., Lingle, C. S., and Valentine, V. B.: Rapid wastage of Alaska glaciers and their contribution to rising sea level, Science, 297, 382-386, 2002.

Beedle, M. J., Dyurgerov, M., Tangborn, W., Khalsa, S. J. S., Helm, C., Raup, B., Armstrong, R., and Barry, R. G.: Improving estimation of glacier volume change: a GLIMS case study 
of Bering Glacier System, Alaska, The Cryosphere, 2, 33-51, doi:10.5194/tc-2-33-2008, 2008.

Berthier, E.: Volume loss from Bering Glacier (Alaska), 19722003: comment on Muskett and others (2009), J. Glaciol., 56, 555-557, 2010.

Berthier, E., Schiefer, E., Clarke, G. K. C., Menounos, B., and Rémy, F.: Contribution of Alaskan glaciers to sea-level rise derived from satellite imagery, Nat. Geosci., 3, 92-95, 2010.

Bhatt, U. S., Zhang, J., Tangborn, W. V., Lingle, C. S., and Phillips, L.: Examining Glacier Mass Balances with a Hierarchical Modeling Approach, Comp. Sci. Eng., 9, 61-67, 2007.

Bjornsson, H.: Hydrological characteristics of the drainage system beneath a surging glacier, Nature, 395, 771-774, 1998.

Burgess, E. W., Forster, R. R., Larsen, C. F., and Braun, M.: Surge dynamics on Bering Glacier, Alaska, in 2008-2011, The Cryosphere Discuss., 6, 1181-1204, doi:10.5194/tcd-6-11812012, 2012.

Cogley, J. G., Hock, R., Rasmussen, L. A., Arendt, A. A., Bauder, A., Braithwaite, R. J., Jansson, P., Kaser, G., Möller, M., Nicholson, L., and Zemp, M.: Glossary of Glacier Mass Balance and Related Terms, IHP-VII Technical Documents in Hydrology No. 86, IACS Contribution No. 2, UNESCO-IHP, Paris, 2011.

Dowdeswell, J. A., Hodgkins, R., Nuttall, A.-M., Hagen, J. O., and Hamilton, G. S.: Mass balance change as a control on the frequency and occurrence of glacier surges in Svalbard, Norwegian High Arctic, Geophys. Res. Lett., 22, 2909-2912, 1995.

Eisen, O., Harrison, W. D., and Raymond, C. F.: The surges of Variegated Glacier, Alaska, USA, and their connection to climate and mass balance, J. Glaciol., 47, 351-358, 2001.

Fatland, D. R. and Lingle, C. S.: Analysis of the 1993-95 Bering Glacier (Alaska) surge using differential SAR interferometry, J. Glaciol., 44, 532-546, 1998.

Fleisher, P. J., Bailey , P. K., Natel, E. M., Muller, E. H., Cadwell, D. H., and Russell, A.: The 1993-1995 surge and foreland modification, Bering Glacier, Alaska, Geological Society of America Special Paper 442, 2010.

Kamb, B.: Glacier Surge Mechanism Based on Linked Cavity Configurationof the Basal Water Conduit System, J. Geophys. Res., 92, 9083-9100, doi:10.1029/JB092iB09p09083, 1987.

Korn, D.: "Modeling the mass balance of the Wolverine Glacier Alaska USA using the PTAA model", American Geophysical Union, Fall Meeting 2010 http://adsabs.harvard.edu/abs/ 2010AGUFM.C21C0560K, 2010.

Lingle, C. S. and Fatland, D. R.: Does englacial water storage drive temperate glacier surges?, Ann. Glaciol., 36, 14-20, 2003.

Mayo, L. R., Meier, M. F., and Tangborn, W. V.: A system to combine stratigraphic and annual mass balance systems: A contribution to the IHD, J. Glaciol., 11, 3-14, 1972.

Meier, M. F.: Proposed definitions of mass balance terms, J. Glaciol., 4, 252-261, 1962.

Meier, M. F. and Post, A. S.: What are glacier surges?, Can. J. Earth Sci., 6, 807-817, 1969.
Merrand, Y. and Hallet, B.: Water and sediment discharge from a large surging glacier: Bering Glacier, Alaska, USA, summer 1994, Ann. Glaciol., 22, 233-240, 1996.

Molnia, B. F. and Post, A.: Holocene history of Bering Glacier, Alaska: A prelude to the 1993-1994 surge, Phys. Geogr., 16, 87$117,1995$.

Molnia, B. F. and Post, A.: Surges of the Bering Glacier. Geological Society of America Special Papers 2010, 462, 291-316, doi:10.1130/2010.2462(15), 2010.

Muskett, R. R., Lingle, C. S., Tangborn, W. V., and Rabus, B. T.: Multi-decadal elevation changes on Bagley Ice Valley and Malaspina Glacier, Alaska, Geophys. Res. Lett., 30, 1857, doi:10.1029/2003GL017707, 2003.

Muskett, R. R., Lingle, C., Sauber, J, Post, A., Tangborn, W., Raubus, B., and Echelmeyer, K.: Airborne and spaceborne DEM and laser altimetry-derived surface elevation and volume changes of the Bering Glacier system, Alaska, USA, and Yukon, Canada, 1972-2006, J. Glaciol., 190, 316-326, 2009.

Nelder, J. A. and Mead, R.: A simplex method for function minimization, Comput. J., 7, 308-312, 1965.

Post, A.: Periodic surge origin of folded moraines on Bering Peidmont Glacier, J. Glaciol., 11, 219-226, 1972.

Röthlisberger, H.: Water pressure in intra- and subglacial channels, J. Glaciol., 11, 177-203, 1972.

Tangborn, W. V.: Using low-altitude meteorological observations to calculate the mass balance of Alaska's Columbia Glacier and relate it to calving and speed. Report of a Workshop, 28 February-2 March 1997, Byrd Polar Research Center, Report No. 15, 1997.

Tangborn, W. V.: A Mass Balance Model that Uses Low-altitude Meteorological Observations and the Area-Altitude Distribution of a Glacier, Geogr. Ann. A, 81, 753-765, 1999.

Tangborn, W. V.: The PTAA Mass Balance Model, Mountain Views, The Newsletter of the Consortium for Integrated Climate Research in Western Mountains, Cirmount, Vol 6. No. 2, November, 2012.

Tangborn, W. and Rana, B.: Mass Balance and Runoff of the Partially Debris-Covered Langtang Glacier, Debris-Covered Glaciers, edited by: Nakawa, M., Raymond, C. F., and Fountain, A., IAHS Publication 264, 2000.

Tangborn, W. V., Krimmel, R. M., and Meier, M. F.: A comparison of glacier mass balance by glaciological, hydrological and mapping methods, South Cascade Glacier, Washington, Snow and Ice-Symposium-Neiges et Glaces (Proceedings of the Moscow Symposium, August 1971 Actes du Colloque de Moscou, août 1971), IAHS-AISH Publ. No. 104, 1972.

Zhang, J., Bhatt, U. S., Tangborn, W. V., and Lingle, C. S.: Response of Glaciers in Northwestern North America to Future Climate Change: an Atmosphere/Glacier Hierarchical Modeling Approach, Ann. Glaciol., 46, 283-290, 2007a.

Zhang, J., Bhatt, U. S., Tangborn, W. V., and Lingle, C. S.: Climate downscaling for estimating glacier mass balances in northwestern North America: Validation with a USGS benchmark glacier, Geophys. Res. Lett., 34, L21505, doi:10.1029/2007GL031139, 2007b. 